\title{
Pentingnya nilai informasi laporan keuangan pada bisnis halal di Pondok Pesantren Kota Palembang
}

\author{
${ }^{1)}$ Mutiara Maimunah \\ mutiara@ukmc.ac.id \\ ${ }^{2)}$ Novita Febriany \\ novita@ukmc.ac.id \\ ${ }^{1,2)}$ Fakultas Bisnis Akuntansi Universitas Katolik Musi charitas
}

\begin{abstract}
This study aims to analyze and determine the influence of organizational culture, human resource capacity, and the use of information technology on halal business on the value of financial statement information in Palembang Islamic boarding school. This type of research is quantitative research. The population in this study were 29 Islamic boarding schools in Palembang. The sampling technique uses saturated sampling technique. Data collection techniques using survey techniques by distributing 87 questionnaires to Islamic boarding school administrator that contain a list of questions to respondents directly and data analysis techniques used are multiple regression analysis techniques. The results showed that organizational culture, human resource capacity, and the use of information technology had a positive effect on the value of financial statement information.
\end{abstract}

Keywords: $\quad$ organizational culture; human resource capacity; information technology; financial statements

\section{Pendahuluan}

Organisasi sektor publik merupakan organisasi yang berfokus pada penyediaan kebutuhan dan pelayanan kepada masyarakat. Umumnya, organisasi sektor publik berada dibawah naungan pemerintah. Sebagai lembaga penyelenggara pelayanan publik, organisasi sektor publik memiliki tanggungjawab untuk memberikan pelayanan terbaik agar tercipta kesejahteraan masyarakat. Salah satu contoh dari organisasi sektor publik adalah pondok pesantren. Pondok pesantren merupakan salah satu organisasi sektor publik yang menyediakan layanan pendidikan dan keagamaan. Sebagai bagian dari organisasi sektor publik, pondok pesantren dituntut untuk dapat mengelola organisasi dengan dilandasi prinsip akuntabilitas dan transparansi.

Dalam menjalankan kegiatannya, pengelolaan pondok pesantren tentunya memerlukan dana. Rencana atau target penerimaan pendapatan pondok pesantren dapat bersumber dari santri, konstribusi individu atau organisasi, dari pemerintah dan atau hasil usaha pesantren (Sulthon \& Khusnuridlo, 2006). Umumnya, pondok pesantren memiliki usaha sampingan yang berfungsi sebagai profit center dimana hasil usaha tersebut sedikit banyak dapat menambahkan pendapatan pondok pesantren yang biasa dikenal sebagai bisnis halal. Global Islamic Economy Indonesia melaporkan bahwa belanja (spending) pada industri halal di dunia sangat besar yakni 218,8 miliar pada tahun 2017. Kondisi tersebut belum dapat dilampaui oleh Indonesia walaupun secara global Indonesia berada di peringkat 10 dari 15 negara. 
Industri halal di Indonesia masih belum digunakan secara maksimal, seperti yang diketahui bahwa Negara Indonesia memiliki jumlah terbesar pembeli produk makanan halal yang mencapai nilai 197 miliar dollar, lalu menyusul Turki yang mencapai 100 miliar dollar. Adanya peluang tersebut maka Bank Indonesia dan beberapa lembaga pemerintah lainnya seperti departemen perindustrian dan perdagangan memfasilitasi pondok pesantren dalam mengembangkan ekonomi syariah. Selain pengembangan ekonomi syariah, hal ini juga dapat mendorong kemandirian ekonomi pesantren dan menjadikan santri yang berkualitas dengan semua aspek kehidupan. Dengan adanya bantuan berupa dana dari pihak luar pesantren, maka pihak pesantren harus dapat memberikan pertanggungjawaban kepada pihak-pihak tersebut. Pertanggungjawaban tersebut dapat dilakukan oleh pihak pesantren dengan membuat suatu laporan keuangan untuk memberikan informasi terkait bantuan dana yang telah diberikan. Oleh karena dalam laporan keuangan yang dipublikasikan oleh pihak pesantren akan banyak pihak yang mengandalkan informasi, baik sebagai pertanggungjawaban ataupun dasar untuk pengambilan keputusan, maka informasi yang harusl berguna bagi para pemakai dan mempunyai nilai. Untuk dapat membuat laporan keuangan yang memiliki nilai informasi yang baik dan berkualitas sehingga bersifat informatif dan mudah dipahami para pemakai maka laporan keuangan harus memenuhi kriteria kualitatif laporan keuangan (Suwardjono, 2005).

Beberapa faktor yang dapat mempengaruhi nilai informasi laporan keuangan yaitu, budaya organisasi, kapasitas sumber daya manusia, dan yang terakhir pemanfaatan teknologi informasi. Faktor pertama, budaya organisasi adalah suatu bentuk anggapan dasar yang dikenalkan oleh beberapa organisasi yang bertujuan agar menyelesaikan permasalahan yang ada sebagai dampak adanya adaptasi eksternal dan integritas internal yang telah berjalan dengan baik. Budaya organisasi memiliki pengaruh yang berarti terhadap nilai informasi laporan keuangan, hanya saja peran strategis budaya organisasi kurang disadari. Hal ini sesuai dengan penelitiannya Fanani et al. (2017) yang mengungkapkan adanya pengaruh yang signifikan antara variabel budaya organisasi terhadap komitmen organisasi pengurus. Penelitian selanjutnya dari Djuanda \& Tarigan (2016) menyatakan bahwa kinerja keuangan perusahaan berbadan hukum PT di Surabaya dan sekitarnya dapat mempengaruhi budaya organisasi.

Faktor kedua yang dapat mempengaruhi nilai informasi laporan keuangan adalah kapasitas sumber daya manusia. Dalam menjalankan sistem akuntansi, kapasitas sumber daya manusia menghasilkan laporan keuangan yang dapat diandalkan sesuai dengan SAK yang berlaku dan terhindar dari kesalahan yang bersifat material, serta dapat menyajikan fakta terkait informasi keuangan secara jujur. Menurut Alimbudiono \& Fidelis (2004), tanggungjawab dan kompetensi sumber daya bisa diketahui dengan menilai kapasitas sumber daya manusia dengan menjalankan suatu fungsi, termasuk fungsi akuntansi. Hal ini didukung dengan penelitiannya Sonia (2016) menyimpulkan bahwa adanya pengaruh yang berarti antara kapasitas sumber daya manusia terhadap nilai informasi laporan keuangan. Penelitian ini mengemukakan bahwa semakin baik kapasitas sumber daya manusia maka semakin baik laporan keuangan yang dihasilkan. 
Faktor ketiga adalah pemanfaatan teknologi informasi yang saat ini sudah lebih baik sehingga dengan semakin berkembangnya teknologi diharapkan dapat menambah kemampuan pengelolaan keuangan suatu organisasi. Hal ini karena dengan memanfaatkan teknologi informasi maka akan mempercepat pemprosesan transaksi dan penyiapan laporan keuangan. Selain itu, pemanfaatan teknologi informasi juga dapat meminimalisir terjadinya kesalahan dalam menyimpan file dengan jumlah besar dan mengurangi biaya. Untuk bisa mendapatkan hasil laporan keuangan dengan nilai informasi yang berkualitas, maka sistem akuntansi sangatlah penting dalam kapasitas sumber daya manusia. Hal ini sesuai dengan penelitiannya Sitanala (2015) dan Sonia (2016) yang menemukan adanya pengaruh signifikan pemanfaatan teknologi informasi dengan nilai informasi laporan keuangan, dimana jika menggunakan teknologi informasi secara benar maka proses transaksi dapat meningkat, akurasi dalam perhitungan, dan sehingga menghasilkan laporan keuangan yang handal.

Berdasarkan observasi secara langsung saat mengikuti kegiatan seminar tentang bisnis halal pada pondok pesantren di kota Palembang yang diselenggarakan oleh IAI wilayah Sumatera Selatan awal tahun 2019 didapat fakta bahwa sebagian besar pengurus pondok pesantren masih belum memahami dengan benar penyajian laporan keuangan. Penelitian ini didorong keinginan untuk menjadikan semua pondok pesantren mampu menyajikan laporan keuangan sesuai dengan standar akuntansi keuangan yang ada agar laporan yang dibuat dapat diandalkan semua pihak khususnya dalam pelaksanaan bisnis halal.

\section{Tinjauan Pustaka}

\subsection{Budaya Organisasi dan Nilai Informasi Laporan Keuangan}

Budaya organisasi menjadi suatu sistem dengan norma yang diikuti oleh para anggota organisasi yang mampu menjadi pemimpin akan ditentukan dari pengetahuannya terhadap keadaan tempat mereka memimpin. Secara sederhana teori agensi memfokuskan pemimpin mengenai gaya kepemimpinan dan pemahaman situasi serta pengendali dan arah dalam membentuk perilaku dan sikap manajerial yang akan menjadi ciri khas dari setiap organisasi. Budaya organisasi memiliki peran yang mempengaruhi nilai informasi laporan keuangan karena seluruh aktivitas organisasi bisa diukur dan dinyatakan keterlibatannya dengan pencapaian tujuan organisasi di masa depan sesuai dalam visi dan misi organisasi, sehingga semua individu dalam kelompok organisasi bepedoman pada kepercayaan dan norma yang berlaku. Penelitian Djuanda \& Tarigan (2016); Anwar \& Amalia (2010) memperkuat hal tersebut dengan menemukan bahwa budaya organisasi memiliki pengaruh terhadap kinerja keuangan perusahaan. Berdasarkan uraian tersebut maka diajukan hipotesis penelitian sebagai berikut:

$H_{1}$ : Budaya organisasi berpengaruh terhadap nilai informasi laporan keuangan.

\subsection{Kapasitas Sumber Daya Manusia dan Nilai Informasi Laporan Keuangan}

Teori keagenan merupakan konsep yang mendasari laporan keuangan pada pondok pesantren. Dalam laporan keuangan, pondok pesantren berkewajiban menyajikan informasi keuangan yang mempunyai manfaat dan memiliki nilai untuk para pengguna informasi keuangan, sehingga pengguna dapat menilai akuntabilitas dan membuat keputusan dari 
pelaporan keuangan tersebut (Supriyono, 2018). Sumber daya manusia (SDM) pada Pondok Pesantren yang memiliki kapasitas yang baik dapat membentuk nilai informasi keuangan yang bermanfaat dan berkualitas.

Hal-hal seperti latar belakang pendidikan ilmu akuntansi, intensif mengikuti pendidikan dan pelatihan bidang akuntansi, dan pengalaman menggunakan sistem akuntansi, adalah ukuran kapasitas SDM. Berdasarkan hal tersebut, agar bisa menghasilkan laporan keuangan dengan nilai informasi yang berkualitas maka kapasitas SDM yang andal sangat dibutuhkan. Hasil penelitian Sonia (2016); Wansyah et al. (2012) menemukan adanya hubungan antara kapasitas sumber daya manusia terhadap nilai informasi pelaporan keuangan. Surastiani \& Handayani (2015) juga menyimpulkan bahwa kekuatan SDM mempunyai pengaruh positif kepada variabel bobot informasi laporan keuangan Pemerintah Daerah. Selanjutnya Sa'adah et al. (2017); Kartika (2014); Satria (2019) mengungkapkan bahwa sumber daya manusia berpengaruh terhadap kualitas informasi laporan keuangan. Berdasarkan uraian tersebut maka diajukan hipotesis penelitian sebagai berikut:

\section{$\mathrm{H}_{2}$ : Kapasitas sumber daya manusia berpengaruh terhadap nilai informasi laporan keuangan.}

\subsection{Pemanfaatan Teknologi Informasi dan Nilai Informasi Laporan Keuangan}

Pemanfaatan teknologi informasi merupakan ukuran yang melihat pada nilai frekuensi dalam diversitas aplikasi yang digunakan. Pemanfaatan teknologi informasi sangat berhubungan dengan perilaku dalam menggunakan suatu teknologi. Ketika data diolah untuk dijadikan sebagai sumber informasi dimana pengguna memanfaatkan teknologi komputer maka informasi yang didapatkan akan meningkat (Jogiyanto, 2005).

Penyajian informasi keuangan yang bermanfaat dan mempunyai nilai dapat didukung dengan memanfaatan teknologi informasi. Teknologi informasi saat ini sudah meningkat pesat sehingga dengan semakin berkembangnya teknologi, maka diharapkan kemampuan pengelolaan keuangan pondok pesantren menjadi lebih baik. Pemanfaatan teknologi informasi dapat meringankan pekerjaan pelaporan keuangan pondok pesantren sehingga membantu mempercepat proses informasi dan transaksi dalam penyajian pelaporan keuangan.

Pemanfaatan teknologi informasi juga membuka peluang bagi berbagai pihak untuk dapat mengakses, mengelola, dan mendayagunakan informasi keuangan pondok pesantren secara cepat dan akurat serta membantu pihak pemakai laporan keuangan untuk mengambil keputusan. Dengan pemanfaatan teknologi informasi secara benar, maka pengguna akan menghasilkan laporan keuangan secara tepat waktu dan memiliki nilai informasi yang andal dan berkualitas. Wansyah et al. (2012); Sitanala (2015); Susanti (2017); Patiro \& Kawung (2018); Erawati \& Abdulhadi (2018); Silvia dan Azmi (2019) membuktikan adanya hubungan antara pemanfaatan teknologi informasi terhadap nilai informasi pelaporan keuangan. Berdasarkan uraian tersebut maka diajukan hipotesis penelitian sebagai berikut:

$H_{3}$ : Pemanfaatan teknologi informasi berpengaruh terhadap nilai informasi laporan keuangan. 


\section{Metode Penelitian}

Sampel penelitian adalah pengurus pada pondok pesantren di kota Palembang. Data penelitian dikumpulkan menggunakan kuesioner dengan responden pengurus pondok pesantren. Survey ditunjukkan kepada 29 pondok pesantren. Setiap pesantren dibagi sebanyak 3 kuesioner sehingga total kuesioner yang disebar 87 kuesioner, namun demikian dapat yang dapat diolah lebih lanjut dari penelitian ini adalah sebanyak 55 kuesioner.

Pengujian hipotesis dilakukan dengan menggunakan analisis regresi linear berganda dengan tujuan untuk melihat keterkaitan antara variabel independen dengan variabel dependen. Sebelum dilakukannya pengujian, data kuesioner penelitian yang dikumpulkan melalui survey perlu diuji dengan pengujian kualitas data. Uji validitas digunakan dengan tujuan untuk mengetahui keabsahan kuesioner dan mensyaratkan pengujian suatu item yang mencapai nilai signifikansi $>0,05$, sedangkan uji reliabilitas dilakukan untuk menilai konsistensi dari jawaban responden penelitian jika memiliki nilai Cronbach Alpha lebih dari 0,70 (Ghozali, 2016).

\section{Tabel 1. Instrumen Penelitian}

\begin{tabular}{|c|c|c|}
\hline Variabel & Indikator Pengukuran & Pernyataan \\
\hline \multirow[t]{8}{*}{$\begin{array}{l}\text { Budaya Organisasi } \\
\text { Sardjito \& Muthaher (2007) }\end{array}$} & $\begin{array}{l}\text { Inovasi dan pengambilan } \\
\text { resiko }\end{array}$ & $\begin{array}{l}\text { Pondok pesantren mendorong karyawan untuk } \\
\text { bersikap inovatif dalam bekerja khususnya dalam } \\
\text { penyelesaian masalah. }\end{array}$ \\
\hline & $\begin{array}{l}\text { Memperhatikan secara } \\
\text { mendetail }\end{array}$ & $\begin{array}{l}\text { Karyawan di pondok selalu memfokuskan pekerjaan } \\
\text { dan berhati-hati dalam menganalisis. }\end{array}$ \\
\hline & Berorientasi pada & Manajemen pondok pesantren mementingkan \\
\hline & kebermanfaatan & $\begin{array}{l}\text { keluaran khususnya pada kebermanfaatan bagi } \\
\text { berbagai pihak. }\end{array}$ \\
\hline & Berorientasi pada orang & $\begin{array}{l}\text { Pondok pesantren fokus pada individu dimana } \\
\text { keputusan yang ditetapkan selalu dipertimbangkan } \\
\text { agar memiliki dampak yang positif. }\end{array}$ \\
\hline & Berorientasi pada tim & $\begin{array}{l}\text { Pondok pesantren fokus pada tim dimana program } \\
\text { dan kegiatan lebih mementingkan pada kinerja } \\
\text { bersama dibandingkan kinerja personal. }\end{array}$ \\
\hline & Bersifat agresif & $\begin{array}{l}\text { Budaya pondok pesantren bersifat agresif yaitu } \\
\text { membuat anggota bertindak agresif dalam bekerja. }\end{array}$ \\
\hline & Stabilitas & $\begin{array}{l}\text { Budaya pondok pesantren berstabilitas yaitu } \\
\text { memberi penekanan pada stabilitas status quo dalam } \\
\text { perbandingannya dengan pertumbuhan. }\end{array}$ \\
\hline \multirow[t]{5}{*}{$\begin{array}{l}\text { Kapasitas Sumber } \\
\text { Daya Manusia } \\
\text { Griffin (2004) } \\
\text { Alimbudion \& Fidelis (2004) }\end{array}$} & Pendidikan & $\begin{array}{l}\text { Karyawan memiliki latar belakang pendidikan yang } \\
\text { sesuai dengan kapasitasnya untuk melaksanakan } \\
\text { fungsi-fungsi kewenangannya untuk mencapai } \\
\text { tujuan yang efisien. }\end{array}$ \\
\hline & Pelatihan & $\begin{array}{l}\text { Pondok pesantren melaksanakan pelatihan dengan } \\
\text { materi yang dibutuhkan untuk karyawan. }\end{array}$ \\
\hline & Pengalaman & $\begin{array}{l}\text { Karyawan bagian administrasi keuangan telah } \\
\text { memiliki pengalaman bekerja dibidang administrasi } \\
\text { keuangan sebelumnya. }\end{array}$ \\
\hline & Tanggung jawab & $\begin{array}{l}\text { Karyawan mampu menjalankan pekerjaannya } \\
\text { dengan deskripsi jabatan yang jelas. }\end{array}$ \\
\hline & Kompetensi sumber daya & $\begin{array}{l}\text { Karyawan mempunyai pemahaman dan kapasitas } \\
\text { untuk menjalankan tugas. }\end{array}$ \\
\hline
\end{tabular}


Tabel 1. Intrumen Penelitian (lanjutan)

\begin{tabular}{|c|c|c|}
\hline Variabel & Indikator Pengukuran & Pernyataan \\
\hline \multirow[t]{4}{*}{$\begin{array}{l}\text { Pemanfaatan Teknologi } \\
\text { Informasi } \\
\text { Maryono \& Istiana (2008) } \\
\text { Suyanto (2005) }\end{array}$} & $\begin{array}{l}\text { Pemanfaatan teknologi } \\
\text { informasi }\end{array}$ & $\begin{array}{l}\text { Di pondok pesantren terdapat tata cara yang } \\
\text { digunakan untuk membuat, mengubah, menyimpan, } \\
\text { menyampaikan atau mengomunikasikan dan } \\
\text { menyebarkan pesan dan informasi. }\end{array}$ \\
\hline & $\begin{array}{l}\text { Perangkat keras } \\
\text { komputer }\end{array}$ & $\begin{array}{l}\text { Di pondok pesantren tersedia perangkat keras suatu } \\
\text { sistem informasi sebagai suatu unit menyimpan file, } \\
\text { penyimpanan peralatan, penyiapan data, dan } \\
\text { terminal input dan output. }\end{array}$ \\
\hline & $\begin{array}{l}\text { Perangkat lunak } \\
\text { komputer }\end{array}$ & $\begin{array}{l}\text { Di pondok pesantren terdapat sistem perangkat } \\
\text { lunak yang dikembangkan untuk mendistribusikan } \\
\text { data dan informasi. }\end{array}$ \\
\hline & Jaringan dan komunikasi & $\begin{array}{l}\text { Jaringan dan komunikasi di pondok pesantren } \\
\text { merupakan suatu sistem yang menghubungkan } \\
\text { beberapa titik komunikasi yang mampu berinteraksi } \\
\text { antara satu dengan yang lain. }\end{array}$ \\
\hline \multirow[t]{6}{*}{$\begin{array}{l}\text { Nilai Informasi } \\
\text { Laporan Keuangan } \\
\text { FASB (SFAC No. 2) }\end{array}$} & Dapat dipahami & $\begin{array}{l}\text { Bentuk dan istilah dalam laporan keuangan pondok } \\
\text { pesantren merupakan informasi yang mudah } \\
\text { dipahami oleh pemakai sesuai batas pemahaman } \\
\text { pemakai. } \\
\text { Laporan keuangan pondok pesantren menyiapkan } \\
\text { penjelasan yang bermanfaat untuk para pengguna } \\
\text { yang mempunyai pengetahuan dasar mengenai } \\
\text { bisnis halal dalam mengambil keputusan. }\end{array}$ \\
\hline & Keandalan & $\begin{array}{l}\text { Laporan keuangan pondok pesantren memiliki } \\
\text { informasi yang mampu menghasilkan berbagai } \\
\text { alternatif keputusan yang ada. } \\
\text { Laporan keuangan pondok pesantren dapat } \\
\text { membantu para pemakai mengevaluasi transaksi } \\
\text { yang telah lalu dan transaksi kini, memprediksi } \\
\text { transaksi ke depan serta mengoreksi hasil evaluasi } \\
\text { transaksi lalu. }\end{array}$ \\
\hline & Relevansi & $\begin{array}{l}\text { Laporan keuangan pondok pesantren adalah } \\
\text { informasi yg memiliki nilai umpan balik, manfaat } \\
\text { prediktif, ketepatan waktu dan lengkap. }\end{array}$ \\
\hline & Reliabilitas & $\begin{array}{l}\text { Laporan keuangan pondok pesantren memiliki } \\
\text { informasi yang dapat diuji atau diverifikasi, bebas } \\
\text { dari kesalahan, netral atau tidak memihak. }\end{array}$ \\
\hline & Komparabilitas & $\begin{array}{l}\text { Laporan keuangan pondok pesantren memiliki } \\
\text { informasi yang dapat dibandingkan dengan tahun } \\
\text { lalu dan entitas lain. }\end{array}$ \\
\hline & Konsistensi & $\begin{array}{l}\text { Laporan keuangan pondok pesantren konsisten } \\
\text { menerapkan kebijakan akuntansi yang sama dalam } \\
\text { setiap tahunnya. }\end{array}$ \\
\hline
\end{tabular}

\section{Hasil Penelitian dan Pembahasan}

Hasil data penelitian diperoleh dengan cara menyebarkan kuesioner kepada responden. Pondok pesantren di Kota Palembang berjumlah 29. Masing-masing pondok pesantren akan diberikan 3 eksemplar kuesioner, dimana sebanyak 87 kuisioner yang disebar serta jumlah yang dapat diolah ada 55 responden. Hasil pengujian vailiditas menunjukkan bahwa seluruh butir pertanyaan adalah valid dengan $p$ value $<0,05$ sedangkan uji reliabilitas menunjukkan seluruh variabel memiliki nilai cronbach alpha $>0,7$. 
Tabel 2. Uji Validitas dan Reabilitas

\begin{tabular}{ccc}
\hline Variabel Penelitian & Uji Validitas & Uji Reabilitas \\
\hline Budaya Organisasi & 0,302 & 0,722 \\
$\mathrm{X}_{1} .1$ & 0,277 & \\
$\mathrm{X}_{1} .2$ & 0,280 & \\
$\mathrm{X}_{1} .3$ & 0,461 & \\
$\mathrm{X}_{1} .4$ & 0,273 & \\
$\mathrm{X}_{1.5}$ & 0,373 & 0,705 \\
$\mathrm{X}_{1.6}$ & 0,348 & \\
$\mathrm{X}_{1.7}$ & & \\
$\mathrm{X}_{2} .1$ & 0,378 & \\
$\mathrm{X}_{2} .2$ & 0,420 & \\
$\mathrm{X}_{2} .3$ & 0,469 & \\
$\mathrm{X}_{2} .4$ & 0,451 & \\
$\mathrm{X}_{2} .5$ & 0,441 & \\
\hline Kapasitas & & \\
$\mathrm{X}_{3} .1$ & 0,359 & \\
$\mathrm{X}_{3} .2$ & 0,538 & \\
$\mathrm{X}_{3} .3$ & 0,558 & \\
$\mathrm{X}_{3} .4$ & 0,528 & \\
Y.1 & & \\
Y.2 & 0,431 & \\
Y.3 & 0,318 & \\
Y.4 & 0,271 & \\
Y.5 & 0,329 & \\
Y.6 & 0,300 & \\
Y.7 & 0,515 & \\
Y.8 & 0,614 & \\
\hline Nilai Informanformasi & 0,469 &
\end{tabular}

Tabel 3. Hasil Analisis Regresi Berganda

\begin{tabular}{|c|c|c|c|c|c|}
\hline \multirow{2}{*}{ Variabel } & \multicolumn{2}{|c|}{$\begin{array}{c}\text { Unstandardized } \\
\text { Coefficients }\end{array}$} & \multirow{2}{*}{ P value } & \multicolumn{2}{|c|}{ Collinearity Statistics } \\
\hline & B & Std. Error & & Tolerance & VIF \\
\hline (Constant) & 7,761 & 3,547 & $0,033^{*}$ & & \\
\hline Budaya Organisasi $\left(\mathrm{X}_{1}\right)$ & 0,377 & 0,116 & $0,002 *$ & 0,930 & 1,076 \\
\hline Kapasitas SDM $\left(\mathrm{X}_{2}\right)$ & 0,257 & 0,111 & $0,025^{*}$ & 0,937 & 1,068 \\
\hline Pemanfaatan TI $\left(\mathrm{X}_{3}\right)$ & 0,409 & 0,162 & $0,015^{*}$ & 0,877 & 1,140 \\
\hline F Hitung: 11,255 & & & $0,000^{* *}$ & & \\
\hline
\end{tabular}

Keterangan: ** $\operatorname{Sig}<1 \%, * \operatorname{Sig}<5 \%$

Berdasarkan uji regresi pada Tabel 3, variabel budaya organisasi berpengaruh positif terhadap nilai informasi laporan keuangan. Budaya organisasi dapat mempengaruhi nilai informasi laporan keuangan karena keterkaitan dan pencapaian organisasi dapat diukur dari setiap kegiatan yang berdasarkan dalam visi misi suatu organisasi. Sebagai bahan diskusi dapat dilihat dari hasil pengujian butir pertanyaan. Butir pernyataan dengan nilai rata-rata tertinggi adalah pada pernyataan "budaya pondok pesantren bersifat agresif yaitu membuat anggota bertindak agresif dalam bekerja", sementara butir pernyataan dengan nilai rata-rata terendah adalah pernyataan "pondok pesantren mendorong karyawan selalu inovatif dalam bekerja khususnya dalam penyelesaian masalah". Sebagaimana definisi budaya organisasi sendiri adalah moral, sikap, dan tingkat produktivitas karyawan atau anggota organisasi yang merupakan hasil dari suatu iklim atau atmosfir emosi dan psikologis yang ada (Pacanowsky \& Trujillo, 1982), dimana pondok pesantren adalah suatu organisasi yang dikenal memiliki gaya sendiri dalam mempertahankan keberadaannya, dengan seorang kyai sebagai 
pemimpin yang menentukan segala kebijakan yang ada. Hal tersebut menarik untuk menjadi perhatian, karena terbukti bahwa budaya tercipta dari pengaruh pembuat kebijakan itu sendiri sebagaimana definisi sebelumnya. Kyai sebagai tokoh panutan akan membuat anggota organisasi "patuh" sehingga cenderung bertindak agresif ketimbang inovatif, hal tersebut yang mendasari bagaimana pengurus pondok pesantren masih belum menyesuaikan dengan cepat perubahan lingkungan akan adanya kebutuhan penyajian pelaporan keuangan yang sesuai dengan prinsip akuntansi yang berterima umum.

Selanjutnya, hasil pengujian hipotesis variabel kapasitas SDM menyatakan bahwa kapasitas SDM berpengaruh terhadap nilai informasi laporan keuangan. Hal ini dapat dijelaskan bahwa untuk bisa menghasilkan laporan keuangan yang bermanfaat dan mempunyai nilai informasi yang berkualitas maka Pondok Pesantren perlu mempunyai SDM dengan memiliki kapasitas yang kompeten. Rata-rata nilai tertinggi pada butir pernyataan adalah pada pernyataan nomor dua yaitu "Pondok pesantren melaksanakan pelatihan dengan materi yang dibutuhkan untuk karyawan", dan nilai rata-rata terendah adalah pada butir pernyataan nomor satu yaitu "Karyawan memiliki latar belakang pendidikan yang sesuai dengan kapasitasnya untuk melaksanakan fungsi-fungsi kewenangannya untuk mencapai tujuan yang efisien". Hasil rata-rata jawaban responden tersebut mengindikasikan bahwa latar belakang pendidikan staf akuntansi yang bertugas menyajikan laporan keuangan pada pondok pesantren masih banyak yang belum sesuai dengan fungsi yang dijalankan, walaupun pihak manajemen pondok pesantren telah berupaya memfasilitasi staf akuntansinya untuk mengikuti pelatihan-pelatihan bidang akuntansi dan pelaporan keuangan. Tentu saja hal tersebut akan berampak pada hasil penyajian laporan keuangan yang dibuat.

Dalam penelitian ini, pengujian hipotesis variabel pemanfaatan teknologi informasi menunjukkan bahwa pemanfaatan teknologi informasi mempengaruhi nilai informasi laporan keuangan. Hal ini dapat dijelaskan bahwa jika dapat menggunakan teknologi informasi dengan baik maka mendapatkan hasil laporan keuangan secara efisien dan memiliki nilai informasi yang berkualitas. Hasil rata-rata tertinggi untuk butir pernyataannya adalah pada butir pernyataan nomor dua yaitu "di pondok pesantren tersedia perangkat keras suatu sistem informasi sebagai suatu unit menyimpan file, penyimpanan peralatan, penyiapan data, dan terminal input dan output" dan butir pernyataan yang terendah adalah nomor empat yang berbunyi "Jaringan dan komunikasi di pondok pesantren merupakan suatu sistem yang menghubungkan beberapa titik komunikasi yang mampu berinteraksi antara satu dengan yang lain". Nilai tersebut memberikan bukti bahwa keberadaan perangkat keras seperti komputer sudah dimanfaatkan sebagai media input data. Meskipun sistem informasi akuntansi belum berfungsi sebagai media yang mampu menjadi alat komunikasi yang mampu berinteraksi diantara fungsi-fungsi operasional yang ada pada pondok pesantren. Namun pemanfaatan teknologi informasi dapat menghasilkan suatu laporan keuangan yang memiliki nilai informasi laporan keuangan bagi pengguna laporan keuangan khususnya dalam pengambilan keputusan. 


\section{Kesimpulan, Keterbatasan dan Saran penelitian}

Penelitian ini dapat ditarik kesimpulan bahwa budaya organisasi, kapasitas sumber daya manusia, dan pemanfaatan teknologi informasi mempunyai pengaruh terhadap nilai informasi laporan keuangan. Keterbatasan dalam penelitian ini adalah penggunaan kuisioner tertutup sehingga tidak mendapat umpan balik langsung dari responden secara tertulis, disarankan penelitian selanjutnya menambahkan kolom tanggapan yang dapat diisi oleh responden. Nilai R Square sebesar 3,63\% menunjukkan masih banyaknya faktor-faktor lain yang mempengaruhi nilai informasi laporan keuangan, disarankan penelitian selanjutnya dapat menambahkan faktor-faktor lain yang dapat mempengaruhi nilai informasi laporan keuangan. Faktor-faktor yang dapat ditambahkan seperti ukuran perusahaan, dimana pondok pesantren sebagai organisasi sektor publik juga memiliki ukuran atas luasnya jasa yang diberikan, hal tersebut tentunya akan berpengaruh terhadap bentuk pelaporan keuangan yang diberikan (Sururudin, 2017). Faktor selanjutnya adalah pengendalian internal, pondok pesantren dalam melaksanakan kegiatan operasionalnya memiliki suatu sistem pengendalian internal, semakin baik dan berjalannya SPI suatu pondok pesantren akan memberikan pengaruh terhadap nilai informasi laporan keuangan (Sulianti 2012; Sitawati \& Subchan 2017; Satria 2019). Faktor lainnya yang bisa ditambahkan adalah pengawasan, adanya bantuan dana pengembangan usaha yang merupakan pinjaman bagi pondok pesantren dalam mengembangkan bisnis halalnya membutuhkan pengawasan pada penggunaan dana yang diterima, hal tersebut dapat memberikan dampak pada penyajian laporan keuangan yang dibuat (Patiro \& Kawung 2018; Anwar \& Amalia 2010).

\section{Daftar Pustaka}

Alimbudion, R. S., \& Fidelis. (2004). Kesiapan sumber daya manusia sub bagian akuntansi pemerintah daerah dan kaitannya dengan pertanggungjawaban keuangan daerah kepada masyarakat: Renungan bagi akuntan pendidik. Jurnal Akuntansi dan Keuangan Sektor Publik, 5(2), 18-30.

Anwar, D. S., \& Amalia, D. (2010). Pengaruh tindakan supervisi, budaya organisasi, kepribadian, dan pelatihan terhadap kelengkapan laporan keuangan. Jurnal Akuntansi dan Auditing, 7(1), 17-32.

Djuanda, V. D., \& Tarigan, J. (2016). pengaruh budaya organisasi terhadap kinerja keuangan melalui perilaku manajer atas isu manajemen lingkungan sebagai variabel interveningnya. Jurnal Bussiness Accounting Review, 4(1), 61-72.

Erawati, T., \& Abdulhadi, M. F. (2018). Pengaruh pemahaman sistem akuntansi keuangan daerah, kapasitas sumber daya manusia dan pemanfaatan teknologi informasi terhadap kualitas informasi laporan keuangan Pemerintah Daerah. Jurnal Akuntansi \& Manajemen Akmenika, 15(1).

Fanani, M. A., Abrori, I., \& Rosyadi, N. I. (2017). Pengaruh budaya organisasi dan gaya kepemimpinan terhadap komitmen organisasi pengurus Pondok Pesantren Mahasiswa Al-Jauhar Sumbersari Jember. Prosiding Seminar Nasional dan Call For Paper Ekonomi dan Bisnis, 27-28 Oktober 2017, 326-338 ISBN: 978-602-5617-01-0.

Financial Accounting Standards Board (FASB). (1980). Statement of Financial Accounting Concepts No.2: Qualitative Characteristics of Accounting Information, Stamford, Connecticut.

Ghozali, I. (2016). Aplikasi Analisis Multivariete IBM SPSS 23. Badan Penerbit Universitas Diponegoro. Semarang.

Griffin. (2004). Komitmen Organisasi (Terjemahan), Jakarta: Erlangga. 
Jogiyanto. 2005. Analisis dan Desain System Informasi: Pendekatan Terstruktur Teori Dan Praktek Aplikasi Bisnis. Yogyakarta: Andi.

Kartika, H. R. (2014). Pengaruh kapasitas sumber daya manusia, pemanfaatan teknologi informasi, dan pengendalian intern akuntansi terhadap nilai informasi pelaporan keuangan pemerintah daerah, studi pada Pemerinta Kota Magelang. Jurnal Rekayasa Keuangan, Syariah dan Audit, 3(1), 1-10.

Maryono, Y., \& Istiana, B. P. (2008). Teknologi Informasi \& Komunikasi 1: Yudhistira.

Noor, J. (2014). Metodologi Penelitian. Jakarta: Kencana Prenada Media Group.

Pacanowsky, M. E., \& Trujillo, O. N. (1982). Organizational communication as cultural performance. Paper Presented at the 68th Annual Meeting of the Speech Communication Association, 49pp, 222-944.

Patiro, K. R. T. O., \& Kawung, G. M. V. (2018). analisis pengaruh sistem pengendalian intern pemerintah, pemanfaatan teknologi informasi dan pengawasan daerah terhadap nilai informasi laporan keuangan Pemerintah Daerah. Jurnal Pembagunan Ekonomi dan Keuangan Daerah, 19(8).

Sa'adah, K., Sitawati, R., \& Subchan. (2017). Pengaruh kompetensi sumber daya manusia dan sistem pengendalian intern terhadap kualitas informasi laporan keuangan dengan moderasi pemanfaatan teknologi informasi. Jurnal Ilmu Manajemen dan Akuntansi Terapan, 8(2).

Sardjito, B., \& Muthaher, O. (2007). Pengaruh partisipasi penyusunan anggaran terhadap kinerja aparat pemerintah daerah: budaya organisasi dan komitmen organisasi sebagai variabel moderating. Simposium Nasional Akuntansi $X$.

Satria, C. (2019). pengaruh kapasitas sumber daya manusia dan pengendalian intern secara parsial terhadap nilai informasi pelaporan keuangan Kabupaten / Kota Di Pemerintah Provinsi Sumatera Selatan. Ekonomica Sharia, 5(2).

Silvia, B., \& Azmi, F. (2019). analisis faktor-faktor yang mempengaruhi persepsi pengusaha UMKM terhadap laporan keuangan berbasis SAK EMKM. Jurnal Analisis Bisnis Ekonomi, 17(1), 57-73.

Sitanala, T. F. (2015). Faktor-faktor yang mempengaruhi nilai informasi pelaporan keuangan daerah Maluku. Jurnal Ilmiah, 4(2).

Sonia, D. P. (2016). Pengaruh kapasitas sumber daya manusia, pemanfaatan teknologi informasi, sistem pengendalian intern pemerintah terhadap nilai informasi pelaporan keuangan Pemerintah Daerah. Jurnal Fekon, 3(1).

Sugiyono. (2015). Metode Penelitian Kombinasi (Mix Methods). Bandung: Alfabeta.

Sulthon \& Khusnuridlo. (2006). Manajemen Pondok Pesantern dalam Perspektif Global. Yogyakarta: LaksBang.

Supriyono, R. A. (2018). Akuntansi Keperilakuan. Yogyakarta: UGM Press.

Surastiani, D. P., \& Handayani, B. D. (2015). Analisis faktor-faktor yang mempengaruhi kualitas informasi laporan keuangan pemerintah daerah. Jurnal Dinamika Akuntansi, 7(2), 139-149.

Susanti, F. (2017). pengaruh kapasitas sumber daya manusia dan pemanfaatan teknologi informasi terhadap kualitas informasi laporan keuangan pemerintah daerah. Jurnal Akuntansi dan Manajemen, 5(1), 69-80.

Suwardjono. (2005). Teori Akuntansi: Perekayasaan Pelaporan Keuangan. Edisi 3. Yogyakarta:BPFE Yogyakarta.

Suyanto, M. (2005). Pengantar Teknologi Infomasi untuk Bisnis. Andi, Yogyakarta.

Wansyah, H., Darwanis., \& Bakar, U. (2012). pengaruh kapasitas sumber daya manusia, pemanfaatan teknologi informasi dan kegiatan pengendalian terhadap nilai informasi pelaporan keuangan SKPD pada Provinsi Aceh. Jurnal Akuntansi Pascasarjana Universitas Syiah Kuala, 43-58. 